\title{
Etika Distribusi Dalam Ekonomi Islam
}

\author{
Atok Syihabuddin

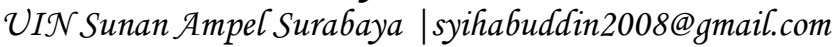

\begin{abstract}
Humans interact with other humans to exchange potentials, whose goal is to create more diverse interactions. In this interaction sometimes humans become predators for other humans. Under these conditions, Islam is present to impose its limitations, in the form of news, orders, and prohibitions. One of the prohibitions in the Qur'an is the spin and the circulation of wealth only on the wealthy people, so it needs to be a fair distribution of wealth. The discussion in this paper begins with a discussion of the distribution and ethics, so that raises the various concepts of ethical axioms of some of the opinions of Muslim Economists. The Islamic economic system departs from an awareness of ethics, in contrast to other economic systems. Furthermore, will be described Islamic philanthropy as a manifestation of the axiom of distribution ethics, both obligatory and sunnah philanthropic. Through these philanthropic teachings, Islam wants to reduce the negative nature of human beings, even make it as a buffer of Islam (Rukun Islam). That is, without implementing it means someone's Islam will collapse. This is a realistic account of the ethical distribution initiated by Islam. Implementation of Islamic philanthropy and accompanied by knowledge of sharia is the first step in the form of community welfare.
\end{abstract}

\begin{abstract}
Abstrak: Manusia berinteraksi dengan manusia lainnya untuk saling bertukar potensi, yang tujuannya agar tercipta interaksi yang lebih beragam. Dalam interaksi ini terkadang manusia menjadi pemangsa bagi manusia yang lain. Dalam kondisi seperti ini Islam hadir untuk memberikan batasan-batasannya, berupa kabar, perintah, dan larangan. Salah satu larangan dalam al-Qur'an adalah berputar dan beredarnya kekayaan hanya pada orangorang yang kaya saja, sehingga perlu adalam distribusi kekayaan yang adil. Pembahasan dalam tulisan ini diawali dengan pembahasan tentang distribusi dan etikanya, sehingga memunculkan berbagai konsep aksioma etika dari beberapa pendapat Ekonom Muslim. Sistem ekonomi Islam berangkat dari kesadaran tentang etika, yang berbeda dengan sistem ekonomi yang lain. Selanjutnya
\end{abstract}




\begin{abstract}
diuraikan filantropi Islam sebagai wujud dari aksiologi etika distribusi, baik filantropis wajib maupun sunnah. Melalui ajaran filantropi ini, Islam ingin mereduksi sifat negatif manusia, bahkan menjadikannya sebagai penyangga keislaman (rukun Islam). Artinya, tanpa melaksanakannya berarti keislaman seseorang akan runtuh. Ini merupakan aksilogi nyata atas etika distribusi yang digagas oleh Islam. Pelaksanaan filantropi Islam dan dibarengi dengan pengetahuan syariah merupakan langkah awal dari wujudnya kesejahtraan masyarakat.
\end{abstract}

Kata kunci: kebutuhan, distribusi, etika, filantropi

\title{
A. Pendahuluan
}

Tyson, mengutip Maslow, menggolongkan kebutuhan hidup dari tingkat sederhana hanya untuk sekedar bertahan hidup (basic need) hingga pada tingkat kemewahan yang digunakan untuk aktualisasi diri (self actualisation). ${ }^{1}$ Dalam rangka memenuhi kebutuhan, kekayaan harus terdistribusi secara adil. Berbicara tentang distribusi, pasti berbicara tentang kebutuhan. Berbicara tentang kebutuhan pasti bersinggungan dengan kepuasan (utility), karena manusia dalam memenuhi kebutuhan juga akan mempertimbangkan kepuasaan maksimal.

Termasuk salah satu fitrah manusia adalah dorongan berusaha untuk memenuhi kebutuhan. Dalam rangka memenuhi kebutuhan, manusia diberi kekuasaan untuk memiliki (owner) berbagai kekayaan, baik kekayaan berwujud maupun kekayaan tak berwujud. ${ }^{2}$ Al-Qur'an

1 Shaun Tyson dan Tony Jackson, Perilaku Organisasi (The Essence Of Organizational Behavior) terj. Deddy Jacobus dan Dwi Prabantini, (Yogyakarta: Andi, 2000) h. 20-21.

2 Rahmat Syafei, Fiqih Muamalah, (Bandung: Pustaka Setia, 2001), h. 38. Berdasarkan QS. al-Baqarah (2): 29, yaitu:

bahwa semua penciptaan di bumi ini pada dasarnya untuk manusia. Bahkan menurut kalangan Hanafiyyah dan Dhāhiriyyah, komoditi yang najis pun boleh dimanfaatkan secara shar'y (muntafa' shar'an). Perspektif 'urfiy memandang bahwa setiap yang secara lumrah diakui 
menyebut bahwa kekayaan merupakan hiasan bagi manusia. ${ }^{3}$ Ayat tersebut yang pertama disebut sebagai perhiasan adalah wanita. Dijadikannya wanita yang disejajarkan dengan kekayaan-kekayaan materi lain tidak berarti manusia, dalam hal ini wanita, disamakan dengan barang. Sangat tidak bisa dipahami jika al-Qur'an mempersamakan manusia dengan barang. Maka yang dimaksud wanita dalam ayat ini harus takwil sebagai kekayaan tak berwujud. Hal ini sebagaimana hadis tentang wanita shalihah sebagai perhiasan dunia. ${ }^{4}$ Sifat shalih yang sematkan kepada sosok wanita merupakan sifat yang abstrak. Sifat itu kemudian bisa dimunculkan dalam bentuk yang kongkrit berupa sikap-sikap yang baik.

Manusia sering kali melupakan etika saat memenuhi kebutuhan. Atas nama memenuhi kebutuhan, manusia akan memangsa manusia lain sebagaimana ungkapan bahasa

memiliki nilai ekonomis layak dikomersilkan meskipun hanya berupa bentuk pemanfaatan yang tidak semestinya, seperti kemampuan menghibur binatang dengan music. Lihat: Tim Laskar Pelangi, Metodologi Fikih Muamalah Diskursus Metodologis Konsep Interkasi Sosial Ekonomi, (Kediri: Lirboyo Press, 2015), h. 7-8.

${ }^{3}$ QS. Âli 'Imrān (3): 14.

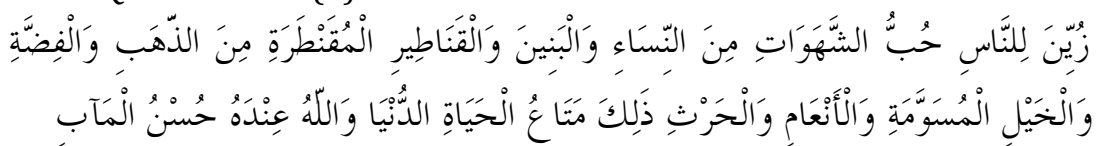

Artinya: "Dijadikan indah pada (pandangan) manusia kecintaan kepada apa-apa yang diingini, yaitu: wanita-wanita, anak-anak, harta yang banyak dari jenis emas, perak, kuda pilihan, binatang-binatang ternak dan sawah ladang. Itulah kesenangan hidup di dunia, dan di sisi Allah-lah tempat kembali yang baik (surga)."

${ }^{4}$ Diriwayatkan oleh Muslim No. 2668 dalam kitab menyusui:

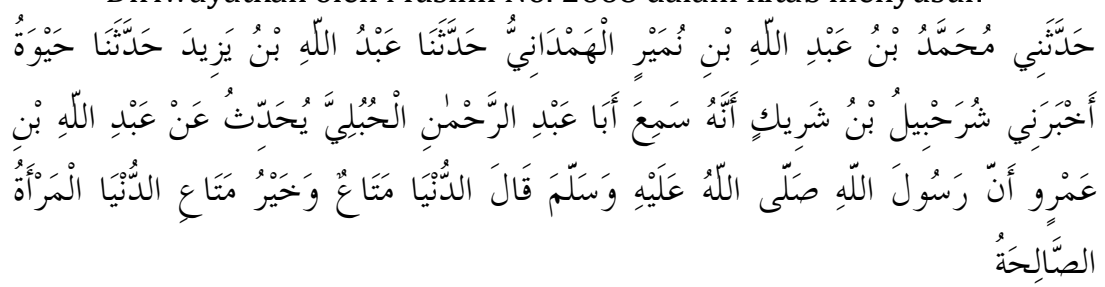


latin: homo momini lupus. ${ }^{5}$ Sifat jelek manusia untuk memangsa manusia lain agar bisa memperoleh segala kebutuhan sudah tergambar oleh ajaran Islam. Oleh karenanya melalui teks ayat-ayat suci al-Qur'an maupun Hadis menyebutkan banyak larangan-langan berbuat kedzaliman. Bahkan dalam hadis qudsi, dalam rangka melarang manusia saling berbuat dzalim, Allah mencontohkan dirinya sendiri untuk tidak berbuat dzalim. ${ }^{6}$ Al-Qur'an juga menyebutkan larangan memakan harta orang lain dengan bațil. Larangan ini bahkan disebutkan dalam redaksi yang sama pada dua ayat yang berbeda. ${ }^{7}$

Tidak dipungkiri bahwa dalam kehidupan terdapat kaum mustad'afin. Mereka tidak mampu mengakses ekonomi dengan baik. Namun demikian, tidak berarti para kaum mustad'afin luput dari perhatian. Negara wajib menjamin bahwa ada kekayaan yang terdistribusi bagi

5 Teori ini pertama kali dimunculkan oleh Thomas Hobbes. Menurut Hobbes, manusia secara naluri memiliki sifat keras. Manusia juga cenderung hanya mementingkan dirinya sendiri. Oleh karenanya, untuk mempertahankan dirinya, manusia bisa saja akan muncul naluri "wild" (kebuasannya).

6 Diriwayatkan oleh Muslim No. 2577 dengan derajat hadis shahih dalam sebuah hadis yang panjang. Poin pada masalah ini adalah:

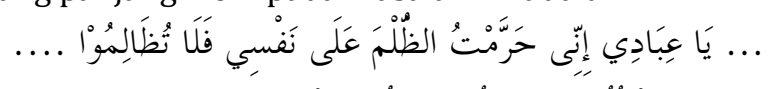

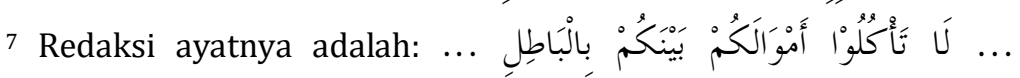

Redaksi pertama ada di QS. Al-Baqarah (2): 188. Konteks ayat pada ayat tersebut berkenaan dengan pengaduan dihadapan hakim. Maksudnya, jangan sampai seseorang mengklaim dan mengajukan tuntutan kemeja hijau atas harta orang lain, dengan merekayasa saksi dan qarinah untuk mempengaruhi hakim. Lihat: Wahbah al-Zuhayly, Tafsir al-Munir , juz 2 (Damaskus: Dār al-Fikr al-Mu'āṣir, 1418 H.), h. 168. Redaksi kedua berada di QS. Al-Nisā' (4) 29. Pada redaksi kedua, Larangan memakan harta orang lain dengan cara yang batil ini berkaitan dengan jual beli. Maksud dari bi al-bāțil pada ayat tersebut adalah memakan harta orang lain tanpa ada ganti. Yang demikian ini adalah memakan harta orang lain tanpa melalui akad yang disyariatkan. Lihat: ibid., juz 5, h. 31. Lihat pula: Tim Guru Besar Tafsir, Tafsïr al-Muyassar, (Madinah: Majma' al-Malik Fahd li Ṭabā'ah al-Muṣhạaf al-Sharif, 2009), h. 83 
mereka untuk memenuhi kebutuhan pokoknya. Ajaran filantropis Islam memberikan tuntunan untuk mendermakan sebagian untuk kepada orang lain dengan berbagai macam nama, dari yang wajib sampai yang sunnah. Yang wajib misalnya: zakat, diyah, kaffarah. Sedangkan yang sunnah seperti infak, sedekah, wakaf. Selanjutnya perlu diurai lebih lanjut bagaimana ajaran filantropi Islam ini mempengaruhi distribusi kekayaan dan bagaimana distribusi kekayaan yang beretika akan berdampak pada hukubungan antropologis ummah.

\section{B. Distribusi dan Etika}

Distribusi menurut KBBI adalah penyaluran (pembagian, pengiriman) kepada beberapa orang atau ke beberapa tempat. ${ }^{8}$ Collins mengartikan Distribusi sebagai proses penyimpanan dan penyaluran produk kepada pelanggan. Menurut penulis definisi yang disampaikan Collins merupakan arti sempit dari distribusi. Collins hanya mengaitkan distribusi dengan proses hasil produksi yang meliputi penyimpanan dan penyaluran.

Anas Zarqa mengartikan distribusi sebagai transfer pendapatan atau kekayaan antara individu dengan cara pertukaran melalui pasar atau dengan cara lain seperti warisan, sedekah, wakaf dan zakat. Definisi ini lebih luas dan komprehensif dari pada definisi yang dikemukakan Collins. Collins dalam mengartikan distribusi hanya fokus pada transaksaksional.

Sedangkan Anas Zarqa mengartikan distribusi tidak hanya melalui mekanisme traksaksional perdangan, melainkan melalui transaksi sosial. Pendapat Anas Zarqa dilengkapi oleh $M$. Abdul Mannan dengan membagi distribusi menjadi distribusi kekayaan dan distribusi

${ }^{8}$ Admin, "Distribusi", dalam https://kbbi.web.id/distribusi, diakses 20/10/2017. 
pendapatan. $^{9}$ Jika distribusi berkenaan dengan pemanfaatan faktor produksi, Mannaan mengklasifikasikannya sebagai distribusi pendapatan, seperti upah dan sewa. Sedangkan distribusi kekayaan adalah distrubusi yang tidak melibatkan faktor produksi, seperti warisan.

Konsep distribusi dalam Islam tergambar melalui surat Alhasyr ayat 7.10 Ayat ini menghendaki distribusi yang merata. Maqașíid al-shari'ah Distribusi kekayaan pada ayat tersebut tersurat jelas agar harta tidak hanya berputar diantara orang-orang kaya saja.

Al-Tha'laby membagi harta peruntukan umat menjadi tiga macam. Pertama, harta yang diambil dari kaum muslim untuk membersihkan harta seperti zakat. Pendistribusiannya sudah dijelaskan dalam Al-Qur'an yang berupa delapan golongan.

Kedua, adalah ghanimah. Harta ini diperoleh kaum muslim setelah melakukan peperangan atau perjanjian damai dengan kaum kafir. Pendistribusian harta ghanimah juga dijelaskan dalam al-Qur'an pada mulanya hanya untuk Allah SWT. dan Rasul-Nya saw. ${ }^{11}$ Kemudian turun lagi ayat mengatur ulang pendistribusian harta ghanimah, yaitu 1/5 bagian untuk Allah SWT. dan Rasul-Nya saw. sedangkan $4 / 5$ (sisanya) dibagikan kepada pasukan. ${ }^{12}$ Ayat ini menasakh ayat sebelumnya.

9 M. Abdul Mannan, Teori dan Praktek Ekonomi Islam, terj. Potan Arif Harahap. (Yogyakarta: Dana Bhakti, 1993), h. 111-121.

10 QS. Al-Hashr (59): 7:

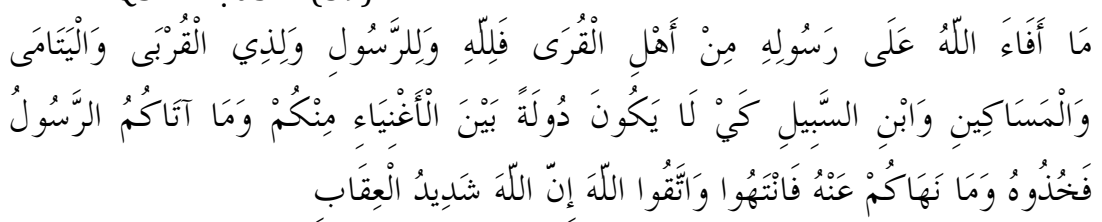

11 Pembagian harta ghanimah awalnya sebagaimana dalam QS. al-

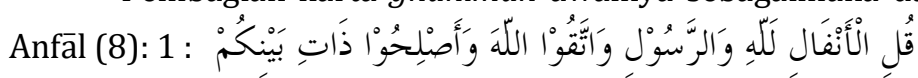

12 QS. al-Anfāl (8): 41: 
Jenis harta umat yang ketiga adalah fai'. Harta fai' adalah harta yang didapat dari kaum kafir yang menyerah tanpa ada peperangan, seperti tebusan perdamaian, jizyah, kharaj, ushr, atau orang kafir yang meninggal tanpa ada pewaris. Distribusi harta fai' kebalikan dari harta ghanimah: 4/5 bagian untuk Rasul sedangkan 1/5 sisanya untuk, keluarga Rasul, yatim, miskin dan ibnu sabil. ${ }^{13}$ Semua ayat tersebut mengajarkan prinsip distribusi kekayaan dalam sistem kehidupan Islami. Al-Quran telah menetapkan aturan tertentu guna mencapai sasaran keadilan dalam pendistribusian kekayaan.

Walaupun ajaran Islam secara tegas memperjuangkan terciptanya keadilan distribusi, kenyatannya keadilan distribusi tidak serta merta tercipta. Mohammad Najib dalam penelitiannya terhadap kehidupan nelayan menyimpulkan bahwa para nelayan di jawa masih belum bisa meningkatkan taraf hidup dalam rangka menciptakan distribusi yang berkeadilan. Hal ini cukup mengherankan padahal mayoritas mereka beragama Islam. Faktor agama tidak mampu memberi dorongan nelayan untuk memiliki etika kerja seperti perilaku hemat, disiplin, menjauhi perilaku konsumtif dan jujur, sebagai modal dasar adanya sikap kewiraswastaan. ${ }^{14}$ Menurut Afzalur

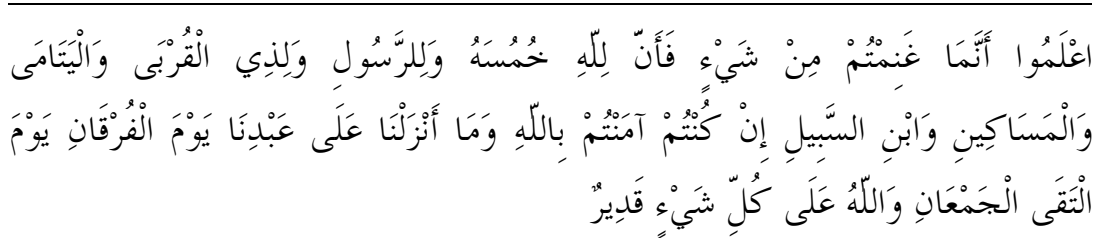

Menurut ayat ini, seperlima bagian dari ghanimah untuk Rasul. Bagian untuk Rasul itu kemudian dibagi lagi menjadi lima masing-masing untuk Rasul, keluarga Rasul, yatim, miskin dan ibnu sabil. Lihat: Abū Abdillah Sufyān al-Thauriy, Tafsir al-Thauriy, (Beirut: Dār al-Kutub, 1983), h. 123.

${ }^{13}$ Abu Ishāq al-Tha'labiy, al-Kasyf wa al-bayān 'an Tafsir al-Qur'an, (Beirut: Dār Ihya' al-Turath, tt), h. 153.

${ }^{14}$ Mochammad Najib, "Agama, Etika dan Etos Kerja Dalam Aktivitas Ekonomi Masyarakat Nelayan Jawa", Jurnal Ekonomi dan Pembangunan, Vol. 21, No. 2, Desember 2013, h. 140. 
Rahman, keadilan dalam ekonomi ideal hanya akan diperoleh dengan adanya kesadaran bahwa segala bantuan ekonomi dan kebaikan kepada sesama merupakan tabungan yang akan kekal di akhirat kelak. ${ }^{15}$ Artinya, menurut Afzalur Rahman, agama hanya berupa nilai-nilai luhur yang tidak akan operasional secara otomatis. Nilainilai luhur itu harus dioperasionalkan oleh ummatnya. Hanya dengan meyakini bahwa nilai luhur agama yang dioperasionalkan dalam tindakan merupakan tabungan kemakmuran, umat beragama menjalankan ajaran agamanya dengan ringan dan semangat.

Kebanyakan manusia dalam memenuhi kebutuhannya tidak cukup puas hanya sekedar memenuhi kebutuhan. Mereka lebih cenderung bermewah-mewahan atas nama pengaktualisasian diri. Kenyataan yang demikian justru didukung oleh para pakar ekonomi, misalnya Galbraith yang mengatakan "Konsumsi barang yang telah menjadi sumber kenikmatan yang paling besar, adalah tolak ukur prestasi manusia yang paling tinggi". ${ }^{16}$ Dengan demikian simbol-simbol gengsi palsu akan terus dipromosikan. Bahkan ekonomi konvensional memberikan pernyataan pembenaran dengan membuat teori bahwa kebutuhan manusia dibuat agar tidak terbatas, tidak pernah terpuaskan, dibandingkan keinginan manusiawi yang sesungguhnya. Di sini pokok masalah yang mendasar, semua merasa memiliki kebebasan yang sebebas-bebasnya untuk membuat apa saja yang dia inginkan. Sebebasbebasnya dimaksudkan sebagai pilihan tingkah laku mereka hanya dipengaruhi oleh rasionalitas belaka. ${ }^{17}$ Pilihan rasionalitas ini bisa diartikan sebagai pilihan

15 Afzalurrahman, Doktrin Ekonomi Islam, terj. Soeroyo, (et.al.) (Yogyakarta: Dana Bhakti Wakaf,1995), h. 63.

16 Joe K. Galbraith, The New Industrial State, (New York: New American Library, 1972), h. 162.

17 M. Umer Chapra, The Future of Economics: An Islamic Perspective, terj. Amdiaar, (et.al.) (Jakarta: Syariah Economic and Banking Institute, 2001), h. 23. 
keputusan-keputusan yang menghindarkan mereka terjun kepada keadaan yang lebih buruk. ${ }^{18}$

Menyikapi pandangan ekonomi di atas, Islam bangkit dan memberikan tawaran cara hidup yang berimbang dan koheren, dirancang untuk kebahagiaan (falah). ${ }^{19}$ Falah dapat terwujud dengan cara menciptakan keharmonisan antara kebutuhan moral dan material dan aktualisasi keadilan sosio-ekonomi serta persaudaraan dalam masyarakat manusia. Inilah urgensi memasukkan unsur etika dalam ekonomi. Konsep ekonomi Islam adalah konsep yang diridlai untuk seluruh umat manusia dan selaras dengan fitrah manusia, serta menjunjung tinggi kepentingan pribadi maupun masyarakat. Konsep ini telah diuji coba selama lebih delapan abad, sejak zaman Rasulullah saw. sampai berakhirnya khilafah Turki Usmani. Dalam hal ekonomi, ekonomi Islam bukan wacana baru dalam dunia sosial dan ilmiah. Ia merupakan suatu realitas yang terus menghadirkan kesempurnaan dirinya di tengahtengah beragamnya sistem sosial dan eknomi konvensional yang berbasis pada faham materialisme sekuler. Ia juga merupakan realitas ilmiah yang senantiasa menampakkan jati dirinya di antara konstelasi ilmu-ilmu sosial yang juga berbasis sekularisme bahkan ateisme. Di dalam kedua arus tersebut, ekonomi Islam mewakili sebuah kekuatan baru yang sedang membentuk dirinya untuk menjadi sebuah sistem dan diskursus yang matang serta mandiri dalam penalaran ilmiah. Kehadirannya bukan saja menjadi

18 Adiwarman A. Karim, Ekonomi Mikro Islami (Jakarta: IIIT Indonesia, 2003), h. 81.

19 Pada dasarnya falah tidak hanya sebagai tujuan berekonomi, tetapi jauh lebih dari itu falah merupakan tujuan hidup. Falah dalam istilah al-Qur'an (QS. (3) :104, (7) :8 dan157, (9): 88, (23):102, (25): 51) sering dimaknai sebagai keberuntungan jangka panjang, dunia dan akhirat, sehingga tidak hanya memandang aspek material namun justru lebih ditekankan pada aspek spiritual. Lihat: Pusat Pengkajian dan Pengembangan Ekonomi Islam, Ekonomi Islam, (Jakarta: Rajawali Pers, 2009), h. 2. 
jawaban dari ketidak adilan sistem sosio-ekonomi kontemporer, melainkan juga sebagai kristalisasi usaha intelektual yang telah berlangsung sangat panjang dalam kurun waktu sejarah kaum muslimin. ${ }^{20}$

Ekonomi Islam harus memiliki prinsip tauhid karena prinsip tauhid merupakan sumber utama dalam ajaran Islam. Prinsip inilah yang wajib pertama ditanamkan dalam kalbu umat Islam sebagaimana yang dilakukan oleh Rasulullah. Priode makkah Rasulullah menanamkan konsep tauhid dengan porsi perhatian lebih daripada praktek ubudiyah. Demikian juga komposisi ayat-ayat makiyah. Pada periode Makkah, porsi ayat tauhid lebih dominan daripada yang ayat hukum. Dalam kaitannya dengan sistem ekonomi Islam, tauhid merupakan sumber utama dalam ajaran Islam yang percaya penuh terhadap Allah SWT. dan merupakan dimensi vertikal. Menciptakan hubungan manusia dengan Allah Swt dan penyerahan tanpa syarat manusia atas segala perbuatan untuk patuh pada perintahNya, sehingga segala yang dilakukan saat melakukan aktifitas ekonomi harus sesuai dengan apa yang digariskan oleh Allah. ${ }^{21}$

Untuk menjamin terwujudnya kemaslahatan individu dan masyarakat, sistem ekonomi Islam menyediakan beberapa landasan teoritis, sebagai berikut:

1. Keadilan ekonomi.

2. Jaminan sosial.

3. Pemanfaatan sumber-sumber daya ekonomi produktif secara efisiensi. ${ }^{22}$

Manusia merupakan mahluk moral. Toshihiko Isutzu menyebutkan bahhwa dirkursus morralitaas dan etika

20 Sa'îd Sa'ad Martān, Ekonomi Islam di Tengah Krisis ekonomi, terj. Ahmad Ikrom, (Jakarta: Zikrul Hakim, 2004), h. iv.

21 Ruslan Abdul Ghofur Noor, Konsep Distribusi dalam Ekonomi Islam: dalam Format keadilan ekonomi di Indonesia (Yogyakarta: Pustaka Pelajar, 2013), h. 63.

22 Mawardi, Ekonomi Islam, (Pekanbaru: Alaf Riau, 2007), h. 23. 
dalam al-Qur'an bertujuan memberikann pedoman bagi manusia dalam berbuat yang berimplikasi keadilan sosial karena menegaskan gambaran manusia sebagai mahluk religious. ${ }^{23}$ Ditarik kedalam wilayah yang lebih sempit lagi, Etika jika dibenturkan dengan keadilan distribusi dapat dirinci menjadi beberapa poin antara lain sebagai berikut:

1. Selalu menghiasi amal dengan niat ibadah dan ikhlas.

2. Transparan, dan barangnya halal serta tidak membahayakan.

3. Adil, dan tidak mengerjakan hal-hal yang dilarang di dalam Islam.

4. Tolong menolong, toleransi dan sedekah.

5. Tidak melakukan pameran barang yang menimbulkan persepsi negatif.

6. Tidak pernah lalai ibadah karena kegiatan distribusi. ${ }^{24}$

7. Ikhtikar dilarang karena akan menyebabkan kenaikan harga.

8. Mencari keuntungan yang wajar. Maksudnya kita dilarang mencari keuntungan yang semaksimal mugkin yang biasanya hanya mementingkan pribadi sendiri tanpa memikirkan orang lain.

9. Distribusi kekayaan yang meluas, Islam mencegah penumpukan kekayaan pada kelompok kecil dan menganjurkan distribusi kekayaan kepada seluruh lapisan masyarakat.

10. Kesamaan Sosial, maksudnya dalam pendistribusian tidak ada diskriminasi atau berkasta-kasta, semuanya sama dalam mendapatkan ekonomi. ${ }^{25}$

Syed Nawab Haider Naqvi menunjuk empat aksioma etika yaitu tauhid, keseimbangan, kehendak bebas dan

23 Toshihiko Isutzu, Ethico Religious Concepts in The Qur'an (Montreal: McGill University Press, 1966), 3

${ }^{24}$ Sofyan S. Harahap, Etika Bisnis dalam Perspektif Islam, (Jakarta: Salemba Empat, 2011), h. 140.

25 Ahamd Mujahidin, Ekonomi Islam 2 (Riau: Al-Mujtahadah Press, 2010), h. 21. 
pertanggungjawaban. ${ }^{26}$ Empat aksioma itu dapat dijabarkan sebagaimana berikut: pertama, etika tauhid. Tauhid memiliki dua tujuan, yaitu:

1. Mengukuhkan bahwa manusia adalah makhluk teomorfik. Maksudnya, manusia adalah mahluk ilahiyah, wujudnya sebagai makhluk tetapi akhlaknya harus meniru akhlak Tuhan.

2. Mengukuhkan fungsi inteegraative dari tauhid. Manusia adalah satu kesatuan dari manusia lainnya. Manusia tidak bisa berdiri sendiri tanpa manusia lain. ${ }^{27}$ Kedua, etika keseimbangan adalah dimensi horizontal antar-manusia sebagai tambahann al-'adl (berbuat aadil) yang merupakan dimensi vertical. Adil hanya bisa dikerjakan dari yang kuat terhadap yang lemah. Keseimbangan berarti tidak berlebih-lebihan dalam mengejaar kepentingan ekonomi. Al-Qur'an melarang sifat berlebihan. ${ }^{28}$ Dengan kata lain, selfishness yang terbatas dilarang oleh Islam. Ukuran berlebihan itu ditentukan oleh masyarakat melalui adat. Masyarakatlah yang menentukan ukuran dan batas berlebihan. ${ }^{29}$

Ketiga, etika kehendak bebas. Manusia sebagai individu dan kolektif memiliki kebebasan penuh dalam menentukan nasibnya sendiri. Jika kehendak bebas ini ditarik dalam ranah ekonomi berarti ada kebebasan penuh untuk mengaktualisasikan dirinya dalam seluruh aktifitas

${ }^{26}$ Syed Nawab Haider Naqvi, Etika dan Ilmu Ekonomi: Suatu Sintesis Islami (Bandung: Mizan, 1985), h. 123-125.

${ }^{27}$ Fadllan, "Konsep Pembangunan Ekonomi Berbasis Islam (sebuah upaya Pembagunan Ekonomi Indonesia yang Adil, Makmur dan Merata)", Al-Hikam: Jurnall Hukum dan Pranata Sosial, Vol. V, No. 2 (Desember 2010), h. 259.

28 QS. al-A'rāf (7): 31 disebutkan larangan berlebih-lebihan dan Allah SWT. tidak suka orang yang berlebih-lebihan

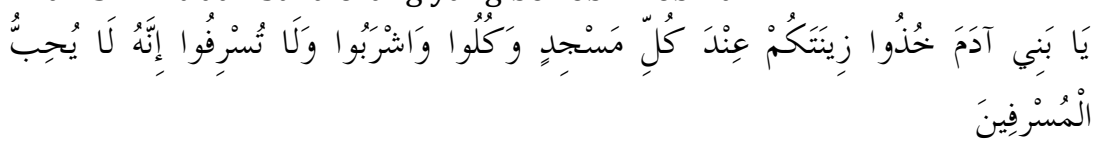

${ }^{29}$ Fadllan, Konsep Pembangunan Ekonomi, h. 259. 
ekonomi. Ekonomi merupakan kegiatan muamalah bukan ibadah. Kaidah yang dipakai adalah semua boleh, kecuali yang dilarang. Islam melarang ketidak adilan dan riba. Riba bukan hanya berrarti bunga atas pinjaman. Ia juga memiliki arti ketidak setaraan dalam pertukaran, baik perbedaan tersebut timbul dari pertukaran jumlahh yang tidak sama ataupun dari adanya resiko yang tidakk ikut dipikul oleh pihak lain dalam kontrak. ${ }^{30}$

Keempat, pertanggungjawaban. Terdiri dari dua: amanah (melaksanakan tanggung jawab) dan accountability (diperhitungkan). Kekayaan adalah amanah Tuhan yang harus dipertanggungjawabkan penggunaannya. Orang yang mampu memikul amanah letaknya adalah surga. ${ }^{31}$ Mengenai accountability, harus dipahami bahwa segala aktifitas di dunia ini pasti akan diperhitungkan kelak di hari pembalasan dihadapan Dzat Yang Maha Tahu dan Maha Teliti. Apapun bentuk dan motivasi manusia beraktifitas, berapapun kecilnya, bagaimanapun samarnya, semua akan masuk dalam criteria perhitungan Tuhan. ${ }^{32}$

Adiwarman Karim menambahkan bahwa selain pondasi tersebut, bangunan ekonomi Islam juga didasarkan pada nilaii universal lainnya, yaitu: 'adl (keadilan), khilaffah (pemerintahan), dan ma'ad (hasil). Dari nilai-nilai tersebut dibangunlah tiga prinsip derivative, yaitu multiple

30 Tentang riba yang paling komprehensif adalah M. Umer Chapra, Towards a Just Monetary System (Londoon: The Islaamic Foundatioon, 1985)

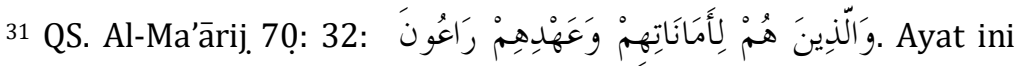
berada pada kumpulan ayat yang menerangkan kriteria penghuni surga. Sejak ayat 21 hingga ayat 35 disebutkan merekalah orang-orang yang dimuliakan di surga.

32 Banyak sekali ayat al-Qur'an dan hadis yang mengabarkan tentang perhitungan Tuhan. Gambaran detail perhitungan Allah, paling tidak tergambar oleh ayat:

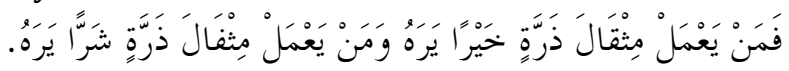


ownership, freedom to act dan social justice. ${ }^{33}$ Hemat penulis, pandangan Fadllan dan Adiwarman Karim mengenai bangunan Ekonomi Islam adalah sama. Hanya beda sudut pandang dalam klasifikasi saja.

Afzalur Rahman menjelaskan bahwa ada beberapa prinsip dan nilai dasar sistem ekonomi Islam, diantaranya: kebebasan individu, hak terhadap harta, ketidak samaan ekonomi dalam batas yang wwajar, kesamaan sosial, jaminan sosial, distribusi kekayaan secara meluas, larangan menumpuk kekayaan, dan kesejaktraan individu dan masyarakat. ${ }^{34}$ Al-Nabhāny lebih spesifik mengklasifikasikan tiga kaidah utama dari hukum-hukum yaaag menyangkut masalah ekonomi, yaitu: kepemilikan, pengelolaan kepemilikan, dan distribusi kekayaan di tengah-tengah manusia. ${ }^{35}$ Konsep distribusi kekayaan lebih detail lagi diajukan oleh Baqir al-Șadr yang membagi distribusi menjadi distribusi pra produksi dan distribusi pasca produksi. ${ }^{36}$ Distribusi pra produksi menggambarkan distribusi faktor-faktor produksi. Distribusi pra produksi mendasarkan pada konsep kepemilikan faktor produksi. Masing-masing benda faktor produksi telah ditentukan stempel kepemilikannya. Distribusi faktor produksi berarti merinci kepemilikan tanah, barang tambang, sumber daya alam, air dan lain sebagainya. Sedangkan distribusi pasca produksi adalah distribusi hasil produksi (pertambahan nilai suatu barang atau jasa karena adanya produksi). Distribusi pasca produksi membahas bagian masingmasing pihak yang terlibat dalam produksi. Bagian-bagian

33 Adiwarman A. Karim, Ekonomi Mikro Islami, h. 34.

${ }^{34}$ Afzalur Rahman, Doktrin Ekonomi Islaam, h. 9.

35 Taqiyyuddin an-Nabhani, Membangun Sitem Ekonomi Al-Ternatif Perspektif Islam,Terj. Moh. Maghfur Wahi (Surabaya: Risalah gusti, 1999) , h. 61.

36 Lebih lengkap tentang distribusi bisa lihat: Atok Syihabuddin, Distribusi Kekayaan (Studi Komparatif Pemikiran Bāqir al-Șadr dan Taqiy al-din Nabhani), (Tesis-UIN Sunan Ampel, 2012). 
ini tentu berdasarkan kesepakatan dalam akad-akad shar'iy.

Dari uraian di atas, dapat disimpulkan bahwa pondasi dasar ekonomi islam adalah kesejahtraan dan keadilan distributive. Pangkal dari seluruh kegiatan ekonomi akan berujung pada dua hal tersebut, dari sudut pandang duniawi. Dari sudut pandang ukhrāwy, ekonomi Islam membangun karakter umatnya dengan menancapkan doktrin hari pembalasan. Jelaslah bahwa seluruh konsep dan teori ekonomi Islam membawa umatnya kepada falah, yaitu sukses di dunia maupun di akhirat.

\section{Filantropi Islam dan aksiologi distribution ethics}

Ekonomi Islam adalah proyeksi dari akidah, syariah, dan moral dalam kegiaatan ekonomi. Ketiga dimensi tersebut menyatu menjadi world view islami. Dalam hal kepemilikan, doktrin world view mengatakan bahwa pemilik sumber daya ekonomi adalah Allah SWT. ${ }^{37}$ Manusia hanya diberi amanat untuk mengelola, mengambil manfaat, dan menjaga kelestariannya. ${ }^{38}$ Dari proses pengelolaan dan pengambilan manfaat ini, manusia dapat mencukupi semua kebutuhan hidupnya serta dalam tataraan tertentu kesejahtraannya akan meningkat. Berkenaan dengan meningkatnya kesejahtraan, dalam ekonomi Islam, manusia dihadapkan pada kewajiban mendistribusikan sebagian dari kesejahtraan tersebut kepada orang lain dalam bentukk zakat, infak, dan sedekah. Dengan demikian kegiatan ekonomi merupakan ketundukan manusia kepada Sang Pencipta untuk menggapai kebahagiaan dunia dan akhirat. Pandangan ini otomatis membantak anggapaan

37 Paling tidak ini diungkapkan dalam beberapa ayat berikut: QS. AlBaqarah (2): 284, QS. Al-Māidah (5): 17 dan QS.al-Ḥadid (57): 7.

38 Masudul Alam Choudhury, Studies in Islamic Social Sciencies (New York \& London: St. Martin's Press Inc. and MacMillan Press Ltd., 1889), h. 27. 
perilaku ekonomi hanya sebatas reaksi untuk bertahan hidup.

Sistem ekonomi Islam berangkat dari kesadaran tentang etika, sebuah ethical economy. Sistem ekonomi kapitalis dan sosialis berangkat dari kepentingan. Kapitalisme berangkat dari kepentingan perorangan (selfishness). Sedangkan sosialissme berangkat dari kepentingan kolektif (colective). Ekonomi berdasar pada etika agama tidak bisa menjadi alat bagi suatu kepentingan. Tugas umat ialah memikirkan bahwa agamanya menghendaki sebuah tatanan ethical economy disatu pihak dan tetap tanggap kepada kepentingan-kepentingan sosial yang nyata dipihak lain. ${ }^{39}$ Kombinasi seimbang ethical economy dan kepentingan sosial ini akan menjadikan distribusi kekayaan merata dan berkeadilan yang pada akhirnya dapat menjadi solusi pengentasan kemiskinan.

Saifuddin menjelaskan ada beberapa hal penting dalam kaitannya dengan zakat, pertama, zakat merupakan salah satu solusi untuk mengentaskan kemiskinan apabila di kelolah dan di salurkan dengan baik. Kedua, secara praktek pengelolaan zakat di Indonesia belum optimal dalam pengelolaan dan penyaluranya, karena belum masih kurangnya standar SDM yang mengelolah dana zakat. Ketiga, bahwa kalau kita lihat dari sejarah, zakat berperan penting terhadap kondisi ekonomi di suatu negara. Keempat, Ada kelemahan-kelemahan dalam pengelolaan zakat yaitu dari aspek yuridis, sosiologis, institusional dan manajemen berdasarkan kelemahan tersebut maka peran negara dalam pengelolan zakat terdapat empat pilar yaitu peran negara sebagai regulator, peran negara sebagai

39 Kuntowijoyo, Identitas Politik Umat Islam (Bandung: Mizan, 1997), h. 135-136. 
fasilitator, peran negara sebagai motivator dan peran negara sebagai distributor. ${ }^{40}$

Adanya sumbatan distribusi akan menyebabkan ketimpangan. Binti Nur Asiyah menggambarkan ketimpangan ekonomi berdampak pada kemiskinan. ${ }^{41}$ Capaian ekonomi pada setiap orang berbeda merupakan sunnatulloh. Sebaliknya perbedaan capaian ekonomi menjadi sebuah ketimpangan. Data sosial ekonomi strategis April tahun 2017 menunjukkan adanya peningkatan pertumbuhan ekonomi tahun 2015 sebesar 4,88 persen, sementara tahun 2016 sebesar 5,02 persen. Namun peningkatan pertumbuhan menunjukkan situasi ekonomi berbeda. Persentase penduduk miskin terjadi di Papua (28,40\%), Papua Barat (24.88\%), NTT $(22,01)$ dan terendah di Jakarta (3,75\%), Bali (4,15\%), Kalsel (4,52\%). Sementara Komoditi yang memberikan pengaruh besar terhadap garis kemiskinan adalah Beras $(18,31 \%$ di perkotaan, 25,35\% di Pedesaan), Rokok $(10,70 \%$ di Perkotaan, 10,70\% di Pedesaan), Daging Sapi (4,98 \% di pedesaan, $3.47 \%$ di perkotaan). Sementara indikator tenaga kerja, pengangguran terbuka untuk wilayah Papua $(3,35 \%)$, Papua Barat (7,46 \%), NTT $(3,25 \%)$, Bali $(1.89 \%$ terendah). Pengangguran terbuka paling tinggi ada di Banten (8.92\%), Jawa Barat (8.63) Kondisi ini membutuhkan satu siklus kebijakan yang mampu memecah kondisi ketimpangan.

Islam memberi jalan atas ketimpangan ekonomi tersebut melalui filantropis wajib yang berupa zakat. Dalam agama, zakat merupakan rukun Islam ketiga. Zakat memiliki peranan yang sangat vital selaiin berhubungan dengannilai ibadah juga menjadi salah satu pilar

40 Saifuddin, “Optimalisasi Distribusi Dana Zakat: Upaya Distribusi Kekayaan (Studi terhadap UU No. 23 Tahun 2011tentang Pengelolaan Zakat)", Azzarqa', Vol. 5, No. 2, Desember 2013, h. 35.

41 Binti Nur Asiyah, "Islam dan Hak Asasi Manusia", Makalah Studi S3 Mata Kuliah Metodologi Studi Islam, tt., h. 5. 
pemerataan ekonomi. Zakat merupakan ibadah yang sangat penting. Allah menerangkan zakat beriringan dengan menerangkan shalat pada 82 tempat. Perkembangan dan potensi zakat di Indonesia sangat bagus. Beberapa penelitian yang dilakukannn di UIN syarif Hidayatullah Jakarta menunjukkan bahwa potensi zakat nasional dapat mencapai Rp. 19,3 triliun. Menurut penelitian BAZNAS, potensi zakat nasional pada tahun 2015 sudah mencapai Rp. 286 triliun. ${ }^{42}$

Sangat disayangkakn ternyata serapan zakat dari masyarakat ternyata jauh dari potensi. Mengapa ini bisa terjadi? Penulis memulai dengan pencarian sifat dasar manusia yang diterangkan oleh al-Qur'an. Manusia dalam al-Qur'an dipanggil dengan insān, ibn $\overline{A d a m}$, bashar. Kata insān disebut sebanyak 65 kali. ${ }^{43}$ Dari semua ayat tersebut, yang menyebutkan kata insān, mayoritas mengabarkan sifat negatif manusia.

Pertama, manusia adalah mahluk yang suka mengeluh. ${ }^{44}$ Ayat ini tepat berada dibawah ayat yang menerangkan tentang pengumpulan harta benda dan penyimpanannya. Sifat mengeluh ini dijabarkan pada ayat berikutnya: "jika manusia ditimpa kesusahan dia berkeluh kesah. Dan bila mendapat kebaikan berupa harta dia jadi kikir". Penyebutan 3 sifat (هلوع، جزوع، منوع) semuanya disebut dalam bentuk isim tafdil. Dalam kaidah bahasa bentuk semacam ini mengandung arti "banyak". Artinya, secara alami manusia ditanamkan sifat banyak mengeluh, banyak berkeluh kesah, dan banyak kikir. ${ }^{45}$ Menurut penulis, bahwa QS. Al-Ma'ārij (70): 19-22 seolah memberitahukan

42 Divisi Publikasi dan Jaringan Puskas BAZNAS, Outlook Zakat Indonesia 2017 (Jakarta: Pusat Kajian Strategis BAZNAS, 2016), h. 6.

43 Muḥammad Fuad 'Abd al-Bāqī, al-Mu'jam al-Mufahras li Alfádz alQurān al-Karīm, (Bandung: Diponegoro, tt.), h. 119.

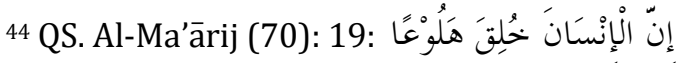

45 Abu Tayib Muhammad Șiddiq Khan al-Husaini, Fath al-Bayān fi Maqașid al-Qur'an, juz 14, (Beirut: Maktabah al-'Așriyah, tt.), h. 316. 
kita bahwa manusia selalu mengeluh baik dalam keadaan cukup tau tidak. Jika ia cukup, ia akan bersifat kikir dan menyimpan kekayaannya, menampakkan ketidak cukupannya. Dan jika manusia kekurangan, ia akan berkeluh kesah, "curhat" kepada sesamanya. Sifat-sifat di atas dikuatkan lagi dalam al-Qur'an, sebagai berikut:

1. Dalam QS. Al-Isrā' (17): 83, yang artinya: "Dan apabila Kami berikan kesenangan kepada manusia niscaya berpalinglah dia; dan membelakang dengan sikap yang sombong; dan apabila dia ditimpa kesusahan niscaya dia berputus asa.".

2. Dalam QS. al-Fușșilat (41): 20 , yang artinya: "Manusia tidak jemu memohon kebaikan, dan jika mereka ditimpa malapetaka dia menjadi putus asa lagi putus harapan."

3. Dalam QS. Al-Isrā' (17): 10, yang artinya: "Katakanlah: "Kalau seandainya kamu menguasai perbendaharaanperbendaharaan rahmat Tuhanku, niscaya perbendaharaan itu kamu tahan, karena takut membelanjakannya." Dan adalah manusia itu sangat kikir."

Kedua, manusia itu suka berlebih-lebihan. Sifat ini disebutkan dalam al-Qur'an sebagai berikut:

1. Dalam QS Yūnus (10) :12, yang artinya: "Dan apabila manusia ditimpa bahaya dia berdoa kepada Kami dalam keadaan berbaring, duduk atau berdiri, tetapi setelah Kami hilangkan bahaya itu daripadanya, dia (kembali) melalui (jalannya yang sesat), seolah-olah dia tidak pernah berdoa kepada Kami untuk (menghilangkan) bahaya yang telah menimpanya. Begitulah orang-orang yang melampaui batas itu memandang baik apa yang selalu mereka kerjakan."

2. Dalam QS. al-'Alaq (96): 6, yang artinya: "Ketahuilah! Sesungguhnya manusia benar-benar melampaui batas."

3. Dalam QS. al-Takāthur (102): 1, yang artinya: "Bermegahmegahan telah melalaikan kamu." 
Sifat bermegah-megahan melengkapi keburukan dari sifat yang pertama (berkeluh kesah dan kikir). Terlebih lagi jika dihubungkan dengan distribusi. Sifat berkeluh kesah dan kikir sangat mengganggu keadilan distribusi. Jika ditambah dengan sifat bermegahmegahan, lengkap sudah potensi terhambatnya distribusi. Artinya, dengan sifat bermegah-megahan, manusia pasti akan menahan hartanya bergerak ke pihak lain. Bahkan kalau bisa, justru kekayaan yang harus sebesar-besaarnya mengalir kepadanya. Sikap berlebih-lebihan juga berpotensi menghambat zakat progressif, ${ }^{46}$ terutama zakat profesi jika pemungutan zakat profesi memperhitungkan kebutuhan. ${ }^{47}$

Ketiga, manusia itu suka kufur nikmat dan tidak pernah puas. Sebagaimana firman Allah SWT. sebagai berikut:

1. Dalam QS. al-Zukhrūf (43): 15, yang artinya: "Dan mereka menjadikan sebahagian dari hamba-hamba-Nya sebagai bahagian daripada-Nya. Sesungguhnya manusia itu benar-benar pengingkar yang nyata (terhadap rahmat Allah)."

2. Dalam QS. al-'Āadiyāt (100): 6, yang artinya: "Sesungguhnya manusia itu sangat ingkar, tidak berterima kasih kepada Tuhannya."

3. Dalam QS. al-Zumar (39): 8, yang artinya: "Dan apabila manusia itu ditimpa kemudharatan, dia memohon (pertolongan) kepada Tuhannya dengan kembali

46 Penulis menggunakan istilah zakat progressif karena pada dasarnya zakat profesi merupakan istilah baru yang belum ada saat proses tasyri'. Namun, progres epistemology zakat hingga memunculkan istilah zakat profesi ini bukan tanpa pijakan hukum. Zakat profesi merupakan hasil ijtihad ulama' berdasarkan Al-Qur'an, Hadis, dan Kiyas. Lihat: Yūsuf al-Qarḍ̄wy, Fiqh al-Zakah (Ttp.: Mu'assasah al-Risālah, 1973), h. 490.

47 Memang ada polemic mengenai pengkiasan zakat profesi. Masih ada perdebatan Apakah zakat profesi itu di kiaskan dengan zakat pertanian atau zakat perdagangan. 
kepada-Nya; kemudian apabila Tuhan memberikan nikmat-Nya kepadanya lupalah dia akan kemudharatan yang pernah dia berdoa (kepada Allah) untuk (menghilangkannya) sebelum itu, dan dia mengadaadakan sekutu-sekutu bagi Allah untuk menyesatkan (manusia) dari jalan-Nya. Katakanlah: "Bersenangsenanglah dengan kekafiranmu itu sementara waktu; sesungguhnya kamu termasuk penghuni neraka."

Sifat kufur nikmat ini yang menjadikan manusia tidak pernah puas jika mendapat nikmat. Seberapapun nikmat yang didapat seringkali manusia lalai dengan kenikmatan itu. Selain itu manusia juga lalai terhadap Yang Memberi Nikmat. Sifat ini juga mengganggu kelancaran distribusi, meskipun Allah memerintahkan mendistribusikan kekayaan dengan zakat dengan perintah keras dan memerintahkan infak dan sedekah dengan perintah anjuran, manusia cenderung akan menyimpan hartanya.

Keempat, manusia itu zalim dan bodoh. Sifat ini dikabarkan oleh Sang Pencipta manusia, yaitu dalam QS. alAhyāb (33): 72, yang artinya: "Sesungguhnya Kami telah mengemukakan amanat kepada langit, bumi dan gununggunung, maka semuanya enggan untuk memikul amanat itu dan mereka khawatir akan mengkhianatinya, dan dipikullah amanat itu oleh manusia. Sesungguhnya manusia itu amat zalim dan amat bodoh."

Itulah sifat psikologi manusia yang digambarkan oleh al-Qur'an. Dalam hubungannya dengan ekonomi, Malakhof memberikan memberikan istilah psikologi ekonomi. Ia mendefinisikan sebagai studi ilmu yang mempelajari hubungan karakteristik psikologi yang terdapat pada individu maupun kelompok dalam aktifitas ekonomi. ${ }^{48}$ Sekumpulan manusia yang hidup bersama

48 Sergei Valer'evich Malakov \& Ivan Evdokimovich Zadorozhniuk, "Economic Psychology and Practice of Running a Modern Economi", dalam Journal of Russian \& East European Psychology,Vol. 31, 1993, h. 9. 
menciptakan lingkungan sosial. Dengan kumpulnya sifat dasar yang dikabarkan ayat-ayat al-Qur'an diatas perlu kiranya dijabarkan prihal sosiologi ekonomi untuk dihubungkan dengan kelancaran distribusi. Sosiologi ekonomi dapat didefinisikan sebagai studi sosiologis yang tujuan utamanaya adalah menganalisis hubungan antara ekonomi dan fenomena sosial. Sosiologi ekonomi akan melihat berbagai fenomena ekonomi sebagai tindakan sosial. Segala institusi ekonomi dipandang sebagai konstruksi sosial. ${ }^{49}$ Dengan demikian yang terlibat bukan hanya ahli ekonomi namun juga melibatkan ahli sosiologi. ${ }^{50}$

Ibnu Khaldun merupakan satu diantara banyak ilmuwan islam klasik terkemuka di bidang ilmu sosial. Dalam bukunya yang berjudul "Muqadimah" memberikan teori sederhana dan menarik yang menunjukkan keterkaitan ilmu-ilmu syariah yang secara fundamental menjadi dasar dari perekonomian dan perpolitikan. Teori tersebut diolah oleh Umer Chapra menjadi suatu model ekonomi sebagai berikut:

$$
\mathrm{S}-\mathrm{N}-\mathrm{W}-\mathrm{D}-\mathrm{J}-\mathrm{G}^{51}
$$

Makna dari siklus tersebut adalah sebagai berikut: $\mathrm{S}$ adalah pemahaman syariah. $S$ harus diajarakan kepada masyarakat untuk membentuk sistem kemasyarakatan yang berlandaskan syariah Islam. ketika pengimplementasian syariah telah berjalan pada suatu kemasyarakatan (N, Nation). Ketika sudah tercipta sistem

49 Granovetter yang dikutip kembali oleh Swedberg, Richard, Entrepreneurship: The Social Science View, (USA: Oxford University Press, 2000), h. 27.

50 Richard Swedberg, Major Traditions of Economic Sociology, Annual Review of Sociology, Vol. 17, 1991, h. 251. Salah satu kontribusi paling signifikan yang dilakukan oleh ekonom datang dari Joseph Schumpeter melalui karyanya: History of Economic Analisys. Ia menggunakan institutional framework dalam menganalisis fenomena ekonomi.

51 M. Umer Chapra, Masa Depan Ilmu Ekonomi: Sebuah Tinjauan Islam, terj. M. Ikhwan Abidin (Jakarta: Gema Insani, 2001), h. 57. 
kemasyarakatan yang berlandaskan syari'ah islam, hingga memengaruhi cara mereka berperilaku dan pengambilan keputusan, lambat laun akan tercipta kesejahteraan atau Wealth (W) di masyarakat. W tersebut tentu akan berefek pada terbayarnya zakat sebagai philanthropy wajib dan tidak menutup kemungkinan juga akan banyak masyarakat yang melengkapinya dengan infaq, Shodaqoh, dan Waqaf. Dengan demikian, terbuka lebar untuk terjadi Development (D), ditandai dengan pembangunan berbagai sarana infrastruktur, lembaga pelatihan, dan lain sebagainya. Kemakmuran dan Pembangunan itu, yang pada akhirnya akan menciptakan keadilan, atau disimbolkan dengan Justice (J) di masyarakat. Ketika perekonomian kuat, maka perpolitikan atau kenegaraan yang disimbolkan oleh Government (G) dapat dikuasai.

\section{Penutup}

Distribusi dalam pandangan para ekonom Islam lebih luas cakupannya dari pada distribusi menurut ekonom konvensional. Distribusi dalam ekonomi konvensional, menitik beratkan pada menyaluran hasil produksi. Sementaraa distribusi dalam ekonomi Islam menitik tekankan pada transfer pendapatan dan kekayaan. Titik tekan utama dalam sistem ekonomi Islam adalah distribusi yang berkeadilan. Distribusi sangat berkaitan erat dengan pemenuhan kebutuhan. Tersumbatnya aliran distribusi mengakibatkan tersumbatnya pemenuhan kebutuhan. Segala yang menyebankan tersumbatnya distribusi adalah haram. Bahkan meskipun penyebab ketersumbatan itu adalah dari harta pribadinya sendiri, misalnya ihtikar (penimbunan), menyimpan harta tanpa mengeluarkan zakat, memanipulasi perputaran kekayaan hanya pada pemilik capital saja, perjudian, dan lain sebagainya.

Untuk memenuhi kebutuhan, manusia akam memangsa manusia yang lain. Pada titik ini, manusia telah 
meninggalkan etika yang telah digariskan oleh agama. Pernyataan Thomas Hobbes ini menguatkan pernyataan alQur'an mengenai sifat-sifat negatif manusia. Beberapa etika dalam distribusi dirumuskann oleh beberapa ahli ekonomi semisal Sofyan S. Harahap, Mujahidin dan terangkum dalam pendapat Nawab Haider Naqvi sebagai berikut: tauhid, keseimbangan, kehendak bebas dan pertanggungjawaban.

Sistem ekonomi Islam berangkat dari kesadaran tentang etika. Hal ini berbeda dengan sistem ekonomi yang lain. Melalui ajaran filantropinya, Islam ingin mereduksi sifat negatif manusia. Filantropi dalam Islam ada yang bersifat wajib dan ada pula yang sunnah. Bahkan untuk filantropi yang wajib, Islam menjadikannya sebagai penyangga keislaman (rukun Islam). Artinya, tanpa melaksanakannya berarti keislaman seseorang akan runtuh. Ini merupakan aksilogi nyata atas etika distribusi yang digagas oleh Islam.

\section{Daftar Pustaka}

Shaun Tyson dan Tony Jackson. Perilaku Organisasi (The Essence of Organizational Behavior) terj. Deddy Jacobus dan Dwi Prabantini. Yogyakarta, Andi, 2000.

Rahmat Syafei. Fiqih Muamalah. Bandung, Pustaka Setia, 2001.

Tim Laskar Pelangi. Metodologi Fikih Muamalah Diskursus Metodologis Konsep Interkasi Sosial Ekonomi. Kediri, Lirboyo Press, 2015

Wahbah al-Zuhayly. Tafsir al-Munīr, juz 2. Damaskus, Dār al-Fikr al-Mu'āṣir, $1418 \mathrm{H}$.

Tim Guru Besar Tafsir. Tafsír al-Muyassar. Madinah, Majma' al-Malik Fahd li Ṭabā'ah al-Muṣhaf al-Sharif, 2009.

Admin. "Distribusi", dalam https://kbbi.web.id/distribusi, diakses 20/10/2017. 
M. Abdul Mannan. Teori dan Praktek Ekonomi Islam, terj. Potan Arif Harahap. Yogyakarta, Dana Bhakti, 1993.

Abū Abdillah Sufyān al-Thauriy. Tafsir al-Thauriy. Beirut, Dār al-Kutub, 1983.

Abu Ishāq al-Tha'labiy. Al-Kasyf wa al-bayān 'an Tafsìr alQur'an. Beirut, Dār Ihya' al-Turath, tt.

Mochammad Najib. "Agama, Etika dan Etos Kerja Dalam Aktivitas Ekonomi Masyarakat Nelayan Jawa", Jurnal Ekonomi dan Pembangunan, Vol. 21, No. 2, Desember 2013.

Afzalurrahman. Doktrin Ekonomi Islam, terj. Soeroyo, (et.al.). Yogyakarta, Dana Bhakti Wakaf,1995.

Joe K. Galbraith. The New Industrial State. New York, New American Library, 1972.

M. Umer Chapra. The Future of Economics: An Islamic Perspective, terj. Amdiaar, (et.al.). Jakarta, Syariah Economic and Banking Institute, 2001.

Adiwarman A. Karim. Ekonomi Mikro Islami. Jakarta, IIIT Indonesia, 2003.

Pusat Pengkajian dan Pengembangan Ekonomi Islam. Ekonomi Islam. Jakarta, Rajawali Pers, 2009.

Sa'ĩd Sa'ad Martān. Ekonomi Islam di Tengah Krisis ekonomi, terj. Ahmad Ikrom. Jakarta, Zikrul Hakim, 2004.

Ruslan Abdul Ghofur Noor. Konsep Distribusi dalam Ekonomi Islam: dalam Format keadilan ekonomi di Indonesia. Yogyakarta, Pustaka Pelajar, 2013.

Mawardi. Ekonomi Islam. Pekanbaru, Alaf Riau, 2007.

Toshihiko Isutzu. Ethico Religious Concepts in The Qur'an. Montreal, McGill University Press, 1966.

Sofyan S. Harahap. Etika Bisnis dalam Perspektif Islam. Jakarta, Salemba Empat, 2011.

Ahamd Mujahidin. Ekonomi Islam 2. Riau, Al-Mujtahadah Press, 2010.

Syed Nawab Haider Naqvi. Etika dan Ilmu Ekonomi: Suatu Sintesis Islami. Bandung, Mizan, 1985. 
Fadllan. "Konsep Pembangunan Ekonomi Berbasis Islam (sebuah upaya Pembagunan Ekonomi Indonesia yang Adil, Makmur dan Merata)", Al-Hikam: Jurnall Hukum dan Pranata Sosial, Vol. V, No. 2 (Desember 2010).

M. Umer Chapra. Towards a Just Monetary System. Londoon, The Islaamic Foundatioon, 1985.

Taqiyyuddin an-Nabhani. Membangun Sitem Ekonomi AlTernatif Perspektif Islam. Terj. Moh. Maghfur Wahi. Surabaya, Risalah gusti, 1999.

Atok Syihabuddin. Distribusi Kekayaan (Studi Komparatif Pemikiran Bäqir al-Ṣadr dan Taqiy al-din Nabhani). Tesis-UIN Sunan Ampel, 2012.

Masudul Alam Choudhury. Studies in Islamic Social Sciencies. New York \& London, St. Martin's Press Inc. and MacMillan Press Ltd., 1889.

Kuntowijoyo. Identitas Politik Umat Islam. Bandung, Mizan, 1997.

Saifuddin. "Optimalisasi Distribusi Dana Zakat: Upaya Distribusi Kekayaan (Studi terhadap UU No. 23 Tahun 2011tentang Pengelolaan Zakat)", Azzarqa', Vol. 5, No. 2, Desember 2013.

Binti Nur Asiyah. "Islam dan Hak Asasi Manusia", Makalah Studi S3 Mata Kuliah Metodologi Studi Islam, tt.

Divisi Publikasi dan Jaringan Puskas BAZNAS. Outlook Zakat Indonesia 2017. Jakarta, Pusat Kajian Strategis BAZNAS, 2016.

Muhammad Fuad 'Abd al-Bāqī. Al-Mu'jam al-Mufahras li Alfädz al-Qurān al-Karim. Bandung, Diponegoro, tt.

Abu Tayib Muhammad Siddiq Khan al-Husaini. Fath alBayān fi Maqașid al-Qur'an, juz 14. Beirut, Maktabah al-'Așriyah, tt.

Yūsuf al-Qarḍāwy. Fiqh al-Zakah. Ttp., Mu'assasah alRisālah, 1973.

Sergei Valer'evich Malakov \& Ivan Evdokimovich Zadorozhniuk. "Economic Psychology and Practice of 
Running a Modern Economi”, dalam Journal of Russian \& East European Psychology, Vol. 31, 1993.

Richard Swedberg. Entrepreneurship: The Social Science View. USA, Oxford University Press, 2000.

Richard Swedberg. Major Traditions of Economic Sociology, Annual Review of Sociology, Vol. 17, 1991.

M. Umer Chapra. Masa Depan Ilmu Ekonomi: Sebuah Tinjauan Islam, terj. M. Ikhwan Abidin. Jakarta, Gema Insani, 2001. 